Jurnal Ilmu Ilmu Agribisnis: Journal of Agribusiness Science, 9(3), Agustus 2021

\title{
ANALISIS PENDAPATAN DAN TINGKAT KESEJAHTERAAN RUMAH TANGGA MASYARAKAT SEKITAR TAMAN NASIONAL BUKIT BARISAN SELATAN KABUPATEN PESISIR BARAT
}

\author{
Income and Welfare Analysis of Community Around the Bukit Barisan Selatan National Park, Pesisir Barat \\ District
}

M. Reza Fachrezy, Zainal Abidin, dan Adia Nugraha

Jurusan Agribisnis, Fakultas Pertanian, Universitas Lampung, J1. Prof. Dr. Soemantri Brojonegoro No. 1 Bandar Lampung 35141, e-mail : adia.nugraha@fp.unila.ac.id

\begin{abstract}
This study aims to determine the socio-economic characteristics of farmers, analyze the income structure, the factors that affect the income of farmers, and the level of household welfare of farmers who live around Bukit Barisan Selatan National Park, Pesisir Barat District. This research is a survey research involving 99 respondents who were randomly selected. Respondents were spread across four subdistricts, namely Bengkunat Belimbing, Ngambur, Pesisir Selatan, and Karya Penggawa Districts. The study was conducted from July to August 2018. The first objective was analyzed qualitatively, the second objective was analyzed using household income analysis, the third objective used multiple linear regression analysis, and the fourth objective was using Sajogyo's criteria (1997). The study suggested that the socio-economic characteristics of the farmers around TNBBS were spread from 15 to 64 years of age with an average age of 43.74 years. The average education level was elementary school, the number of majority of family sizes was from 4 to 6 people (67.68\%), and the average land was $1.41 \mathrm{ha}$. The average household income of farmers is IDR $36,946,883.94$ per year, which consists of on-farm income $63.68 \%$, off-farm income $11.00 \%$, and non-farm income $25.33 \%$. Factors that affect farmers' income are fertilizer costs and labor costs. The welfare of farmers around TNBBS is in quite prosperous category.
\end{abstract}

Key words: characteristics, household income, welfare

\section{PENDAHULUAN}

Taman Nasional Bukit Barisan Selatan terletak di ujung wilayah Barat Daya Sumatera, dengan bagian yang terbagi di daerah Provinsi Lampung (79,12\%) dan Provinsi Bengkulu (20,88\%). Taman Nasional Bukit Barisan Selatan memiliki zona yang bisa dimanfaatkan oleh masyarakat untuk berusaha tani. Zonasi Taman Nasional Bukit Barisan Selatan berdasarkan SK Dirjen PHKA No. SK. 80/IV-KKBHL/2014 tanggal 25 Maret 2014. Zona Pemanfaatan Tradisional (ZPT). Taman Nasional Bukit Barisan Selatan memiliki luas wilayah \pm 2.433 ha. Zona Pemanfaatan Tradisional memberikan akses kepada masyarakat dalam pemanfaatan kawasan hutan secara lestari (Dirjen KSDAE, 2014).

Pembagian wilayah Taman Nasional Bukit Barisan Selatan tersebar di empat kabupaten, bagian wilayah terluas terletak di Kabupaten Pesisir Barat (58,6\%), sementara kawasan lain berada di Kab. Kaur Prov. Bengkulu (20,8\%), Lampung Barat (16,5\%), dan Tanggamus (4,1\%) (Purwanto, 2016).Kabupaten Pesisir Barat memiliki luas \pm 290.773 ha yang terdiri dari 11 kecamatan (BPS, 2018).

Berdasarkan data yang dipublikasikan oleh Badan Pusat Statistik Kabupaten Pesisir Barat tahun 2018 menunjukkan bahwa luas lahan untuk perkebunan lebih luas dari pada lahan persawahan, yaitu $\pm 25.452,2$ ha untuk perkebunan dan \pm 16.248 ha untuk persawahan.

Sektor pertanian memegang peranan sangat penting dalam memberikan kontribusi yang besar bagi pertumbuhan ekonomi petani. Pertumbuhan ekonomi petani tergantung pada tingkat pedapatan dan keuntungan yang diperoleh petani dari sektor pertanian itu sendiri.

Menurut Suratiyah (2009), besarnya pendapatan dipengaruhi oleh dua faktor yaitu faktor internal dan eksternal. Adapun faktor internal terdiri dari umur, tingkat pendidikan, dan luas lahan yang dimiliki oleh petani. Faktor eksternal terdiri dari ketersedian sarana produksi dan harga. Menurut Adalina dkk (2015) karakteristik sosial ekonomi petani meliputi variable umur, tingkat pendidikan, 
jumlah tanggungan, dan luas lahan, dengan demikian karakteristik sosial ekonomi dapat digolongkan sebagai faktor internal yang dapat mempengaruhi pendapatan petani.

Tingkat pendapatan rumah tangga merupakan sebuah indikator penting yang dapat mengetahui taraf hidup sebuah rumah tangga. Rendahnya tingkat kesejahteraan merupakan ciri dari tingkat kemiskinan. Masalah kemiskinan identik dengan keterbatasan dalam kepemilikan dan penguasaan sumberdaya fisik dan non fisik.

Berdasarkan BPS (2019) Kabupaten Pesisir Barat menempati urutan ke empat dengan jumlah penduduk miskin sebesar 22.980 jiwa (14,98\%).

Tingkat kesejahteraan suatu rumah tangga dapat dilihat melalui besarnya suatu pendapatan yang diterima untuk suatu rumah tangga yang bersangkutan (BPS. 1998).

Pengeluaran rumah tangga dibedakan menurut pangan dan non pangan. Kedua jenis pengeluaran tersebut dapat dilihat dari pola pengeluaran yang terjadi dimasyarkat (BPS. 1993). Kesejahteraan bersifat subjektif sehingga ukuran kesejahteraan bagi setiap individu atau keluarga berbeda satu sama lain. Namun, pada prinsipnya kesejahteraan berkaitan erat dengan kebutuhan dasar. Apabila kebutuhan dasar dari individu atau keluarga sudah dapat terpenuhi, maka dapat dikatan bahwa tingkat kesejahteraan dari individu atau keluarga tersebut sudah tercapai.

Berdasarkan uraian diatas, maka tujuan dari penelitian ini adalah mengetahui karakteristik sosial ekonomi masyarakat sekitar Taman Nasional Bukit Barisan Selatan Kabupaten Pesisir Barat, menganalisis tingkat pendapatan rumah tangga petani, menganalisis faktor-faktor yang mempengaruhi tingkat pendapatan petani, dan menganalisis tingkat kesejahteraan rumah tangga petani.

\section{METODOLOGI PENELITIAN}

Penelitian ini dilakukan di sekitar Taman Nasional Bukit Barisan Selatan Kabupaten Pesisir Barat yang terdiri dari lima desa, yaitu Desa Pemerihan, Desa Sukabanjar, Desa Ulok Mukti, Desa Paku Negara, dan Desa Penengahan Laay. Pemilihan lokasi penelitian ditentukan secara sengaja (purposive) dengan pertimbangan Kabupaten Pesisir Barat merupakan kabupaten yang memiliki wilayah Taman Nasional Bukit Barisan Selatan paling luas (TNBBS). Populasi penelitian ini adalah masyarakat yang berada disekitar Taman Nasional Bukit Barisan Selatan baik itu petani maupun rumah tangga yang jumlah populasinya sebanyak 10.908 jiwa. Banyaknya sampel pada penelitian ini ditentukan dengan menggunakan rumus Slovin (Noor. 2012).

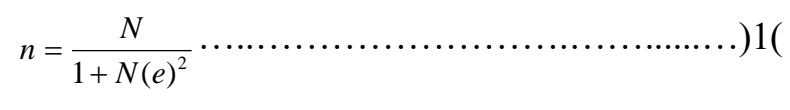

\section{Keterangan:}

$$
\begin{aligned}
\mathrm{n} & =\text { Unit sampel } \\
\mathrm{N} & =\text { Populasi } \\
\mathrm{e} & =\text { Error level (ditetapkan } 10 \% \text { dengan } \\
& \text { tingkat kepercayaan } 90 \%)
\end{aligned}
$$

Berdasarkan rumus, diperoleh jumlah sampel yang diambil pada penelitian ini adalah 99 responden. Penarikan sampel pada penelitian ini menggunakan Probability Sampling, yaitu teknik sampling yang memberikan peluang yang sama bagi setiap unsur (anggota) populasi yang dipilih menjadi anggota sampel (Sugiyono, 2006).

Populasi tersebar pada lima desa, maka jumlah sampel atau responden yang diambil memperhatikan perbandingan jumlah masingmasing desa dengan rumus alokasi proporsional sebagai berikut:

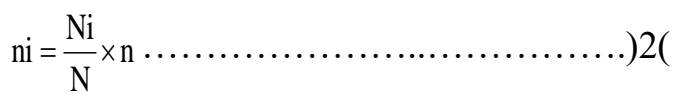

$$
\begin{array}{ll}
\text { Keterangan: } \\
\begin{array}{ll}
\mathrm{ni} & = \\
& \text { Unit sampel pada masing-masing } \\
\mathrm{Ni} & \text { desa } \\
\mathrm{N} & \text { Poluasi kelas } \\
\mathrm{n} & =\text { Populasi keseluruhan } \\
& =\text { Jumlah unit sampel yang ditentukan }
\end{array}
\end{array}
$$

Berdasarkan perhitungan, bahwa 99 responden di dapat perhitungan proporsional jumlah responden pada masing-masing desa di Kabupaten Pesisir Barat, yaitu Desa Pemerihan sebanyak 21 orang, Desa Sukabanjar sebanyak 12 orang, Desa Ulok Mukti sebanyak 23, Desa Paku Negara sebanyak 17 orang, dan Desa Penengahan Laay sebanyak 26 orang.

Karakteristik sosial ekonomi masyarakat sekitar TNBBS Kabupaten Pesisir Barat dianalisis secara deskriptif. Pendapatan rumah tangga petani dianalisis menggunakan rumus pendapatan rumah tangga. Pengkuran pendapatan rumah tangga ini sejalan dengan pengukuran yang digunakan oleh Syakinah (2019). 


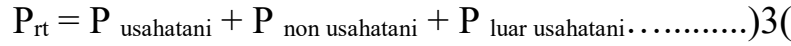

Keterangan:

$\mathrm{P}_{\mathrm{rt}}$

$=$ Pendapatan Rumah Tangga petani per tahun

$\mathrm{P}_{\text {usahtani }} \quad=$ Pendapatan dari usahatani

$\mathrm{P}_{\text {non usahatani }} \quad=$ Pendapatan dari luar pertanian

$\mathrm{P}_{\text {luar usahatani }}=$ Pendapatan dari luar usahatani

Faktor-faktor yang mempengaruhi tingkat pendapatan petani menggunakan analisis regresi linier berganda dengan model sebagai berikut:

$$
\begin{aligned}
\mathrm{Y}= & \beta_{0}+\beta_{1} \mathrm{X}_{1}+\beta_{2} \mathrm{X}_{2}+\beta_{3} \mathrm{X}_{3}+\beta_{4} \mathrm{X}_{4}+\beta_{5} \mathrm{X}_{5}+ \\
& \beta_{6} \mathrm{X}_{6}+\beta_{7} \mathrm{X}_{7}+e \ldots \ldots \ldots \ldots \ldots \ldots \ldots \ldots \ldots \ldots \ldots \ldots \ldots \ldots \ldots \ldots \ldots \ldots \ldots
\end{aligned}
$$

Keterangan:

$\mathrm{Y} \quad=$ Pendapatan

$\beta_{0} \quad=$ Konstanta

$\beta_{\mathrm{i}} \quad=$ Koefisien

$\mathrm{X}_{1} \quad=$ Umur

$\mathrm{X}_{2} \quad=$ Tingkat pendidikan

$\mathrm{X}_{3} \quad=$ Jumlah tanggungan

$\mathrm{X}_{4} \quad=$ Luas lahan

$\mathrm{X}_{5} \quad=$ Biaya pupuk

$\mathrm{X}_{6} \quad=$ Biaya pestisida

$\mathrm{X}_{7} \quad=$ Biaya Tenaga kerja

e $\quad=$ Error

Metode analisis untuk mengukur tingkat kesejahteraan rumah tangga digunakan kriteria kemiskinan Sajogyo (1997). Pengukuran tingkat kesejahteraan ini menggunakan pendekatan pengeluaran rumah tangga/kapita per tahun yang di konversikan ukuran setara beras per kilogram. Pengkuran tingkat kesejahteraan ini sejalan dengan pengukuran yang digunakan oleh Khasanah (2018).

Pengeluaran rumah tangga /kapita per tahun $(\mathrm{Rp})=$

$\frac{\text { Crt }}{\sum \text { anggotakeluarga }}$

Pengeluaran/kapita per tahun setara beras $(\mathrm{Kg})=$

Crt/kapita/tahun ..)6(

Klasifikasi kemiskinan menurut Sajogyo (1997)

a) Paling miskin, apabila pengeluaran/kapita/tahun lebih rendah dari $180 \mathrm{~kg}$ setara nilai beras/tahun.

b) Miskin sekali, apabila pengeluaran/kapita/tahun antara 181-240 kg setara nilai beras/tahun. c) Miskin, apabila pengeluaran/kapita/tahun antara 241-320 kg setara nilai beras/tahun.

d) Nyaris miskin, apabila pengeluaran/ kapita/tahun antara $321-480 \mathrm{~kg}$ setara nilai beras/tahun.

e) Cukup, apabila pengeluaran/kapita/tahun antara 481-960 kg setara nilai beras/tahun.

f) Hidup layak, apabila pengeluaran/kapita/tahun lebih tinggi dari $960 \mathrm{~kg}$ setara nilai beras/tahun.

\section{HASIL DAN PEMBAHASAN}

\section{Karakteristik Responden}

Karakteristik responden dalam penelitian ini dilihat berdasarkan umur, tingkat pendidikan, jumlah tanggungan keluarga, dan luas lahan. Sebesar 90 persen petani tersebar pada kelompok umur 15-64 tahun (usia produktif), dengan tingkat rata rata pendidikan formal sebesar 51,52 persen berada pada tingkat SD.

Jumlah tanggungan keluarga petani berkisar antara 4-6 orang dengan persentase sebesar 67,68. Rtarata luas lahan yang dimiliki petani sebesar 1,41 ha. Karakteristik tersebut menunjukkan bahwa petani dapat menyokong kegiatan usaha tani dengan baik.

\section{Pendapatan Rumah Tangga}

Masyarakat yang berada di daerah penelitian merupakan masyarakat tani, mereka juga melakukan usahatani lain selain usahatani padi dan kebun. Pada umumnya pendapatan rumah tangga pedesaan tidak berasal dari satu sumber, tetapi berasal dari dua atau lebih sumber pendapatan.

Usaha lain yang dilakukan adalah usaha off farm dan non farm. Usaha off farm adalah usaha yang bersal dari luar usahatani, sedangkan usaha non farm adalah usaha yang dilakukan di luar pertanian. Usaha tersebut mereka lakukan guna memberikan tambahan pendapatan lain di luar usahatani yang digunakan untuk memenuhi kebutuhan hidup mereka.

\section{Pendapatan On-Farm}

Pendapatan usahatani (on farm) diperoleh dari pendapatan usahatani, baik itu usahatani padi dan kebun, dari jumlah responden 99 orang, sebanyak 62 responden memiliki lahan kebun dan 37 responden tidak memiliki lahan kebun. Usahatani kebun diperoleh dari kopi, coklat, lada, sawit, damar, duren, jengkol, dan petai. Rata-rata 
Tabel 1. Distribusi pendapatan rumah tangga per tahun masyarakat petani dilokasi penelitian

\begin{tabular}{llll}
\hline \multirow{2}{*}{ No } & $\begin{array}{l}\text { Jenis } \\
\text { Sumber } \\
\text { Pendapatan }\end{array}$ & $\begin{array}{l}\text { Rata-Rata } \\
\text { Pendapatan } \\
(\mathrm{Rp})\end{array}$ & $\begin{array}{l}\text { Persentase } \\
\text { \%o( }\end{array}$ \\
\hline 1 & On Farm & $23.539 .429,39$ & 63,68 \\
2 & Off Farm & $4.065 .050,51$ & 11,00 \\
3 & Non Farm & $9.360 .404,04$ & 25,32 \\
\hline Jumlah & $36.946 .883,94$ & 100,00 \\
\hline
\end{tabular}

pendapatan on farm terbesar bersasal dari usahatani padi yaitu sebesar Rp14.002.868,69 per tahun, sementara usahatani kebun sebesar Rp9.536.560,61 per tahun. Jumla dari rata-rata pendapatan on farm per tahun adalah Rp23.539.429,30.

\section{Pendapatan Off Farm}

Pendapatan di luar usahatani (off farm) adalah pendapatan yang diperoleh masyarakat petani yang berasal dari kegiatan di luar usahatani tetapi masih berkaitan dengan pertanian. Pendapatan diluar usahatani (off farm) berasal dari sektor pertanian diluar usahatani seperti buruh tani, usaha penggilingan padi, dan jual beli produk pertaian

Rata-rata pendapatan off farm terbesar berasal dari jenis pekerjaan sebagai buruh tani yaitu sebesar Rp2.731.717,17 per tahun, usaha penggilingan padi sebesar Rp787.879,79, dan jual beli produk pertanian sebesar Rp545.455,55. Jumlah dari ratarata pendapatan off farm per tahun adalah Rp4.065.050,51.

\section{Pendapatan Non-Farm}

Pendapatan di luar pertanian (non farm) adalah pendapatan yang diperoleh petani dari kegiatan yang tidak berhubungan dengan pertanian. Pendapatan di luar pertanian (non farm) berasal dari lima jenis pekerjaan, yaitu aparatur desa, wiraswasta (berdagang), guru, pegawai, dan tukang bangunan.

Rata-rata pendapatan non farm terbesar bersaal dari jenis pekerjaan sebagai wiraswasta (berdagang) yiatu sebesar Rp5.151.515,15 per tahun, pegawai sebesar Rp1.575.575,58, guru sebesar Rp1.031.313,13, tukang bangunan sebesar Rp818.818,82, dan aparatur desa sebesar
Rp783.636,36. Total dari pendapatan non farm per tahun adalah Rp9.360.404,04.

\section{Analisis Pendapatan Rumah Tangga}

Pendapatan rumah tangga diperoleh dengan cara menjumlah pendapatan keluarga dari pendapatan usahatani (On Farm), pendapatan usahatani di luar kegiatan budidaya usahatani (Off Farm), dan pendapatan di luar usahatani (Non Farm).

Berdasarkan Tabel 1 dapat dilihat jumlah pendapatan rumah tangga di daerah penelitian yang terbagi ke dalam tiga jenis pendapatan, yaitu pendapatan on farm, pendapatan off farm, dan pendapata non farm. Hasil dari perhitugan diperoleh jumlah pendapatan sebesar Rp36.946.883,94 per tahun.

Pendapatan rumah tangga yang paling besar berasal dari pendapatan on farm yaitu Rp23.539.429,39 dengan persentase 63,68 persen Hal ini menujukkan bahwa kegiatan usahatani berperan penting dalam kontribusi pendapatan rumah tangga petani. Pendapatan dari sektor non farm memberikan kontribusi sebesar 25,32 persen sedangkan pendapatan off farm memberikan kontribusi 11,00 persen.

Hasil penelitian ini sejalan dengan penelitian yang dilakukan oleh Canita (2017) yang menyatakan bahwa sumber pendapatan rumah tangga terbesar berasal dari pendapatan on farm yakni sebesar 87,00 persen. Pendapatan dari sektor on farm merupakan sumber pendapatan utama masyarakat, sehingga memberikan kontribuasi pendapatan tertinggi dalam pendapatan rumah tangga masyarakat.

\section{Analisis Regresi Linier Berganda}

Penelitian ini menggunakan analisis regresi linier berganda dengan menggunakan uji asumsi klasik. Analisis regresi dalam penelitian ini dimaksudkan untuk mengetahui pengaruh umur (X1), tingkat pendidikan (X2), jumlah tanggungan (X3), luas lahan (X4), biaya pupuk (X5), biaya pestisida (X6), biaya tenaga kerja (X7) terhadap pendapatan petani dilokasi penelitian (Y). Hasil regresi Uji T dapat dilihat pada tabel 2

Berdasarkan Tabel 2 hasil regresi Uji $\mathrm{T}$ maka diperoleh biaya pupuk $\left(\mathrm{X}_{5}\right)$ dan biaya tenaga kerja $\left(\mathrm{X}_{7}\right)$ memiliki nilai signifikanisi $<\alpha(0,05)$, yaitu 0,009 dan 0,001 yang artinya biaya pupuk dan biaya tenaga kerja berpengaruh terhadap tingkat - 
Tabel 2. Hasil regresi Uji T

\begin{tabular}{|c|c|c|c|c|c|}
\hline \multirow{2}{*}{ Model } & \multicolumn{2}{|c|}{ Unstandardized Coefficients } & \multirow{2}{*}{$\begin{array}{c}\text { Standardized Coefficients } \\
\text { Beta }\end{array}$} & \multirow{2}{*}{$\mathrm{t}$} & \multirow{2}{*}{ Sig. } \\
\hline & $\mathrm{B}$ & Std. Error & & & \\
\hline (Constant) & $9.493 .694,43$ & $7.504 .686,95$ & & 1,265 & 0,209 \\
\hline $\operatorname{Umur}\left(\mathrm{X}_{1}\right)$ & $-3.199,99$ & $95.540,22$ & $-0,002$ & $-0,03$ & 0,973 \\
\hline Tingkat Pendidikan $\left(\mathrm{X}_{2}\right)$ & $-643.722,33$ & $427.722,93$ & $-0,112$ & $-1,51$ & 0,136 \\
\hline Jumlah Tanggungan $\left(\mathrm{X}_{3}\right)$ & $-209.787,51$ & $923.621,42$ & $-0,016$ & $-0,23$ & 0,821 \\
\hline Luas Lahan $\left(\mathrm{X}_{4}\right)$ & $-3.571 .061,87$ & $2.222 .116,89$ & $-0,216$ & $-1,61$ & 0,112 \\
\hline Biaya Pupuk $\left(\mathrm{X}_{5}\right)$ & 6,3 & 2,37 & 0,49 & 2,656 & $0,009 * * *$ \\
\hline Biaya Pestisida $\left(\mathrm{X}_{6}\right)$ & 0,76 & 3,42 & 0,03 & 0,223 & 0,824 \\
\hline Biaya Tenaga Kerja $\left(X_{7}\right)$ & 1,8 & 0,54 & 0,448 & 3,357 & $0,001 * * *$ \\
\hline R Square & & & & & 0,566 \\
\hline
\end{tabular}

pendapatan petani Hasil penelitian ini sejalan dengan hasil penelitian yang dilakukan oleh Ridha (2017) yang menyatakan bahwa tenaga kerja mempengaruhi tingkat pendapatan petani dengan nilai T Hitung sebesar 0,006.

Adapun hasil penelitian dari Neonbota (2016) yang menyatakan bahwa biaya pupuk mempengaruhi tingkat pendapatan petani dengan nilai $\mathrm{T}$ Hitung sebesar 0,010. dijelaskan oleh variasi dari ketujuh variabel bebas yaitu sebesar 56,6 persen sedangkan Hasil dari perhitungan koefisien determinasi $\left(\mathrm{R}^{2}\right)$ sebesar 0,566, hal ini menunjukkan bahwa persentase variasi pendapatan petani yang bisa sisanya sebesar 43,6 persen dijelaskan oleh variabel-variabel lain diluar penelitian.

\section{Analisis Tingkat Kesejahteraan}

Tingkat kesejahteraan rumah tangga petani di Desa Pemerihan, Desa Sukabanjar, Desa Ulok Mukti, Desa Paku Negara, dan Desa Penengahan Laay diukur dengan metode kesejahteraan yang ditetapkan oleh Sajogyo (1997). Kategori kesejahteraan (Sayogyo. 1997) dibagi atas enam kategori yaitu, paling miskin, miskin sekali, miskin, nyaris miskin, cukup dan hidup layak.

Metode ini menggunakan pengeluaran rumah tangga per kapita per tahun. Menurut Sajogyo (1997) pengeluaran rumah tangga per kapita per tahun adalah total pengeluaran rumah tangga petani baik pengeluaran untuk pangan dan non pangan dalam setahun dibagi dengan jumlah tanggungan rumah tangga.

Pengeluaran total per tahun rumah tangga masyarakat sebesar Rp25.372.536,28. Pengeluaran terbesar yang dikeluarkan rumah tangga adalah untuk kebutuhan pangan yaitu sebesar 53,87 persen sedangkan pengeluaran non pangan sebesar 46,13 persen.

Total pengeluaran tersebut kemudian dikonversikan ke dalam ukuran setara beras per kilogram dengan menggunakan harga beras yang berlaku di daerah penelitian untuk mengetahui tingkat kesejahteraan rumah tangga masyarakat.

Tingkat kesejahteraan masyarakat sekitar Taman Nasional Bukit Barisan Selatan berdasarkan kriteria Sayogyo (1997) berada pada kategori cukup 63,64 persen, nyaris miskin 18,18 persen, hidup layak 10,10 persen, miskin 7,07 persen, dan miskin sekali 1,01 persen. Secara keseluruhan maka dapat dikatakan masyarakat sekitar Taman Nasional Bukit Barisan Selatan Kabupaten Pesisir Barat masuk dalam kategori cukup.

\section{Analisis Cross Tab}

Analisis ini digunakan untuk melihat hubungan antara faktor internal variabel $\mathrm{X}$ dengan tingkat kesejahteraan Y. Hasil regresi adalah sebagai berikut;

Berdasarkan Tabel 3 hasil Cross Tab diketahui bahwa faktor internal yang berhubungan dengan tingkat kesejahteraan masyarakat adalah jumlah tanggungan $\left(\mathrm{X}_{3}\right)$ dengan nilai Asymp Sig pada Uji Chi Square $<\alpha(0,05)$ yaitu 0,002 . 
Tabel 3. Hasil Cross Tab

\begin{tabular}{lrrr}
\hline \multicolumn{4}{c}{ Chi-Square Tests } \\
& Value & Df & $\begin{array}{c}\text { Asymp. Sig. (2- } \\
\text { sided) }\end{array}$ \\
\hline Pearson Chi- & $37,887^{\mathrm{a}}$ & 16 & 0,002 \\
Square & 31,946 & 16 & 0,010 \\
Likelihood Ratio & 16 & 0,000 \\
Linear-by-Linear & 18,660 & 1 & \\
Association & 99 & & \\
N of Valid Cases & 99 &
\end{tabular}

Oleh karena itu, dapat disimpulkan bahwa terdapat hubungan yang signifikan antara variabel jumlah tanggungan rumah tangga $\left(\mathrm{X}_{3}\right)$ dengan tingkat kesejahteraan (Y).

Semakin banyak jumlah tanggungan suatu rumah tangga akan berpengaruh pada tingkat pengeluaran rumah tangga. Besarnya jumlah tanggungan berdampak besar pada tingkat kesejahtreaan keluarga jika tidak diimbangi dengan jumlah pendapatan yang sesuai. Hal ini dapat diartikan bahwa jumlah tanggungan rumah tangga seseorang mempunyai korelasi yang positif terhdap tingkat kesejahteraan yang diperolehnya.

\section{KESIMPULAN}

Karekteristik sosial ekonomi masyarakat sekitar TNBBS Kabupaten Pesisir Barat tersebar pada usia 15-64 tahun dengan rata-rata berusia 43,47 tahun, rata-rata tingkat pendidikan SD (51,52\%), mayoritas jumlah tanggungan rumah tangga sebanyak 4-6 orang $(67,68 \%)$, rata-rata dan luas lahan yang dimiliki petani 1,41 ha. Pendapatan rumah tangga masyarakat sebesar Rp36.946.883,94 per tahun, yang diperoleh dari pendapatan on farm sebesar Rp23.539.429,39 per tahun $(63,68 \%)$, pendapatan off farm sebesar Rp4.065.050,51 per tahun $(11,00 \%)$, dan pendapatan non farm sebesar Rp9.360.404,04 per tahun $(25,32 \%)$. Faktor yang mempengaruhi pendapatan usahatani adalah biaya pupuk dan tenaga kerja. Berdasarkan kriteria Sajogyo (1997) kesejahteraan, masyarakat sekitar TNBBS termasuk dalam kategori cukup sejahtera .

\section{DAFTAR PUSTAKA}

Adalina, Y., Nurrochman, R. R., Darusman, D. dan Sundawati, L. (2015). Kondisi Sosial Ekonomi Masyarakat di Sekitar Taman Nasional Gunung Halimun Salak. Jurnal Penelitian Hutan dan Konservasi Alam. 12(2) : 105-118.
Badan Pusat Statistik. 1993. Statistik Kesejahteraan. Badan Pusat Statistik. Jakarta. 1998. Statistik Kesejahteraan. Badan Pusat Statistik. Jakarta. . 2018. Pesisir Barat Dalam Angka. Badan Pusat Statistik. Lampung. . 2019. Provinsi Lampung Dalam Angka. Badan Pusat Statistik Lampung. Lampung.

Canita, P.L., Haryono D, dan Kasymir E 2017. Analisis Pendapatan dan Tingkat Kesejahteran Rumah Tangga Petani Pisang di Kecamatan Padang Cermin Kabupaten Pringsewu. Jurnal Jurnal Ilmu Ilmu Agrbisnis:5(4).(https://jurnal.fp.unila.ac.id/ind ex.php/JIA/article/view/1635/1461).

Sepetember 2020].

Direktorat Jendral Konservasi Sumber Daya Alam dan Ekosistem. 2014. Konservasi Taman Nasional Bukit Barisan Selatan untuk Kesejahteraan Rakyat. Kementerian Lingkungan Hidup dan Kehutanan. Jakarta.

Khasanah, W.N., Murniati K, Widjaya S. 2018. Pendapatan dan Kesejahteraan Rumah Tangga Petani Padi Ladang di Kecamatan Sidomulyo Kabupaten Lampung Selatan. Jurnal Jurnal Ilmu Ilmu Agrbisnis:6(4).(https://jurnal.fp.unila.ac.id/ind ex.php/JIA/article/view/3064/2439).

September 2020].

Neonbota, Sarafina Laka, dan Simon Juan Kune. 2016. Faktor-Fakto yang Mempengaruhi Usahatani Padi Sawah di Desa Haekto Kecamatan Noemuti Timur. Jurnal. Universitas Timor. Kefaminanu

Noor, Juliansyah. 2012. Metodelogi Penelitian. Kencana Prenada Media Grup. Jakarta.

Purwanto, Edi. 2016. Strategi Anti-Perambahan di Tropical Rainforest Heritage of Sumatra: Menuju Paradigma Baru. Bogor. Indonesia: Tropenbos International Indonesia dan UNESCO, xiv +136 hal.

Ridha, Ahmad. 2017. Analisis Faktor-Faktor yang mempengaruhi Pendapatan Petani di Kecamatan Nurussalam Aceh Timur. Jurnal. Universitas Samudra Langsa Aceh. Aceh

Sajogyo, T. 1997. Garis Kemiskinan dan Kebutuhan Minimum Pangan. LPSB-IPB. Bogor.

Saragih. 2010. Agribisnis: Paradigma Baru Pembangunan Ekonomi Berbasis Pertanian. IPB Press. Bogor.

Sugiyono. 2006. Metode Penelitian Kuantitatif Kualitatif dan $R \& D$. Alfabeta. Bandung.

Suratiyah K. 2009. Ilmu Usahatani. Jakarta: Penebar Swadaya. 
Jurnal Ilmu Ilmu Agribisnis: Journal of Agribusiness Science, 9(3), Agustus 2021

Syakinah, F,N., Indriani Y, dan Affandi. 2019. Pendapatan dan Kesejahteraan Rumah Tangga Pembudidaya Lele di Kecamatan Natar Kabupaten Lampung Selatan. Jurnal Jurnal
Ilmu Ilmu

Agrbisnis:7(1).https://jurnal.fp.unila.ac.id/inde x.php/JIA/article/view/3332/2553. September 2020]. 